\title{
ON THE DETERMINANTS OF UNEMPLOYMENT IN NIGERIA: WHAT ARE THE ROLES OF TRADE OPENNESS AND CURRENT ACCOUNT BALANCE?
}

\author{
Isiaka Akande Raifu \\ Isiaka Akande Raifu \\ Department of Economics, Faculty of Economics \\ University of Ibadan, Ibadan, Oyo State, Nigeria \\ heritagetiamiyu@gmail.com \\ Article info \\ Paper category: Original Scientific Paper \\ Received: $29 \cdot 9 \cdot 2017$. \\ Accepted: 4.12.2017. \\ JEL classification: $\mathrm{C}_{2} 3 ; \mathrm{F}_{1} 6 ; \mathrm{J} 64$
}




\begin{abstract}
Attention of international trade and macroeconomic experts has focused on the effect of international trade, precisely trade openness, on economic growth and by extension on unemployment rate, albeit with mixed results. However, scanty attention has been drawn towards the effect of current account balance on unemployment rate despite the arguments from different quarters trailing such relationship. By employing Autoregressive Distribution Lag estimation technique, this study specifically focuses on the short-run dynamic and long-run effects of trade openness and current account balance on unemployment rate in Nigeria using the data that span 1981-2014. We found that trade openness worsens unemployment rate both in the short-run and long run. We also discovered that in the short run, current account balance increases unemployment rate but reduces it in the long run. Control variables used in the study such as inflation rate, exchange rate, and FDI followed a priori expectation while real GDP, wages and government consumption expenditure failed to follow a priori expectation. We, therefore, concluded that there is need for sound trade and macroeconomic policies to aid domestic firms' production to ensure international competitiveness of these firms so as to guarantee employment generation.
\end{abstract}

\title{
Keywords:
}

Trade openness, current account balance, unemployment rate, Autoregressive Distribution Lag Method (ARDL), Nigeria 


\section{INTRODUCTION}

Theoretically, it has been argued in the literature that when an economy is growing at a certain percentage, unemployment rate is expected to reduce by a certain percentage (Okun, 1962). Due to expected gain from trade, economists also believe that international trade tends to promote employment (Brecher, 1974, Davis, 1998, Helpman et al., 2010). However, the real experiences of many countries, particularly developing countries, run contrary to these theoretical assertions as many countries in the world face daunting challenges of rising unemployment despite impressive records of economic growth over the years (Rad, 2011). Nigeria is not an exception. Until recently, Nigerian economy has experienced a remarkable growth in the past decade, particularly in the current democratic dispensation. To be specific, Nigeria became the largest economy in Africa after rebasing her GDP. As a result of rebasing exercise, the value of gross domestic product at nominal face value stood at N80.20 trillion ( $\$ 510$ billion). Similarly, in terms of trade performance measured by net exports $^{1}$, Nigeria has been doing considerably well. For instance, average net exports, over the past decade, stood at $\mathrm{N}_{4,268.52}$ billion. Despite the notable growth and trade performance, the country is still battling with many socioeconomic malaises.

Of all socioeconomic malaises confronting Nigeria, the problem of unemployment has become a chronic one. Over the years, unemployment rate has soared at an alarming rate as many young graduates graduating from the higher institutions are joining the labor market without the capacity to absorb them. Historically, during the first two decades after independent of Nigeria as a country, unemployment was not an issue. This is because majority of citizens during that time resided in rural areas and engaged in farming and those in urban areas were gainfully employed. In other words, unemployment rate as at that time was very low. However, the country made a journey into unemployment when the oil sector took over as a primary driver of the economy (Nwankwo and Ifejiofor, 2014). Since then, unemployment issue has become a thorny one in the country. To buttress this point, the trajectory of unemployment rate shows that unemployment rate in 1967 stood at $1.7 \%$. It, however, grew astronomically over time until it reached $25.10 \%$ in 2014 . (NBS Unemployment Review, 2014).

In search for the causes of soaring unemployment rate in Nigeria, many authors have attributed it to several factors. Fajana (2000) noted that persistence soaring of unemployment figure can be attributed to the long period of initial unemployment among the job seekers or university graduates (otherwise called hysteresis), faulty manpower planning, increase in population, economic recession, collective bargaining process or labor market conditions, rural-urban migration, and formal and informal sector wage differentials. Apart from these, macroeconomic policy

1 Net export is the difference between export and import $(\mathrm{NX}=\mathrm{X}-\mathrm{M})$ where NX is the net export, $\mathrm{X}$ is export and $\mathrm{M}$ is import 
instability and dysfunctional financial system often lead to capital flight which puts limitation on business investment and productivity are also considered to be part of harbingers of soaring unemployment rate (IMF, 2010, Verick and Islam, 2010, Choudhry, et al., 2012).

Empirical studies devoted towards the determinants of unemployment are enormous but the findings are mixed. In other words, agreeable determinants of unemployment are scarce to be found in the literature. The findings depend on so many reasons which include the economic environment in which the study is carried out (Developed or Developing Countries), the kinds of variables the researcher considered, the methodologies he/she employed as well as the scope or period of study considered. On the subject matter of this study which is the examination of trade openness and current account balance as determinants of unemployment, the findings are also mixed, particularly with regards to trade openness. There are ample of studies which concluded that trade openness helps in reducing unemployment (Felbrermayr et al., 2009; Dutt, Mitra and Ranjan, 2007; Kim 2011; Loganathan et al., 2011 and Hassan, et al. 2012). On the other hand, there are also studies which suggested that trade openness aggravates unemployment problem (Egger and Kreickemeier, 2009 and Helpman and Itskhoki 2010). Some even concluded that trade openness has no significant impact on unemployment (Moore and Ranjan, 2005). While there are batteries of theoretical and empirical studies on the relationship between trade and unemployment, most of the studies that examine the relationship between current account (either deficit, surplus or balance) and unemployment are theoretical with scanty empirical studies (details in literature review).

In the light of this, we set to re-examine trade openness as a determinant of unemployment rate in Nigeria using recently rebased dataset with 2010 as base year. Besides, we also provide first-hand empirical evidence on the effect of current account balance on unemployment rate. While Hojjat, (2014) examined the relationship between current account balance and unemployment in the United States using both descriptive and Ordinary Least Squares approaches, thus depicting only a long run relationship between the two variables, we seek to examine the short-run dynamic and long-run effects of both trade openness and current account balance on unemployment rate. This we do by using a novel approach developed by Pesaran et al., (2001), known as Autoregressive Distribution Lag (ARDL) method. ARDL has several advantages over the convention way of estimation short-run and Long-run impact of one or more variables on other variable such as Error Correction Model (ECM). One of these advantages of ARDL estimation technique is that it is employable irrespective of the order of integration of our variables of interest. Also, it enables us to simultaneously determine the short run dynamic and long run impact of independent variables and dependent variable.

As a preview to findings, our results showed that current account balance could either reduce or aggravate unemployment rate depending on the time dimension 
under consideration and economic conditions. However, it is apparent that current account balance worsens unemployment rate in the short run but reduces it in the long run. In addition, we also discover that trade openness worsens unemployment rate both in the short run and the long run. Macroeconomic variables considered in the study have mixed effect on unemployment rate. For instance, inflation rate, exchange rate, and FDI tend to reduce unemployment rate in both runs. While government consumption expenditure and compensation of employee tend to increase unemployment rate, the real GDP, a measure of economic performance, has no significant effect on unemployment rate in Nigeria.

The rest of the study is organized as follows. Section two presents an extensive review of extant theoretical and empirical findings. Section three provides methodology approach employed, data sources and description. In section four, we present our findings and discussion while section five concludes and offers policy recommendations.

\section{REVIEW OF EXTANT LITERATURE}

\subsection{Theoretical Literature Review}

On the one hand are the theories of unemployment and on the other hand are the theories of trade and how trade affects the economy and employment (unemployment). Among the theories of unemployment ${ }^{2}$, I consider two important theories of unemployment. This includes Classical theory of Unemployment and Keynesian Theory of Unemployment. This is followed by theories of trade and how they are related to employment (unemployment).

\subsubsection{Classical Theory of Unemployment}

Classical theory of unemployment has two arms that describe the determinants of unemployment; they are labor demand and labor supply. Labor demand, a derived demand, is a function of wages and it is negatively sloped downwards, which implies that as wage increases demand for labor declines and vice versa. The labor supply, on the other hand, is a function of labor force and the willingness to either supply labor or not (leisure) which is also a function of real wage. In equilibrium, the intersection of labor demand and labor supply produces a unique equilibrium of wages and employment. Classical theory of unemployment which is predicated on the assumptions of free market and perfect competition among others does not believe in any involuntary unemployment as it believes that the economy is always at full employment. Unemployment can only arise, according to the classical economists, when there are distortions in the free market such as mismatch in the labor market which may result

2 See Mouhammed, (2011) for an excellent review of theories of unemployment 
from excess supply over demand for labor. This scenario can be self-corrected by the invisible hand of market demand and supply of labor.

\subsubsection{Keynesian Theory of Unemployment}

Keynesian theory of unemployment has its root traced to the work of the British born economist, John Maynard Keynes entitled, "The General Theory of Unemployment, Interest and Money." The Keynesian Theory of Unemployment links employment to effective demand for goods and services produced by firms under the assumption of fixed prices. Thus, aggregate demand produces an income at a given price which leads to the employment of new workers. This implies that employment changes when aggregate demand changes. On the supply side, Keynes postulated that labor supply, as in classical theory, is a function of real wage, however not flexible due to the labor bargaining power. This implies that wages may remain unchanged in the face of surplus of labor supply. The mismatch between labor supply and the intersection of labor demand and spiral wages give rise to involuntary unemployment. In other words, unemployment in Keynesian theory is owing to cyclicality or deficiency in aggregate demand.

Based on the two theories above, several models have being developed to provide lucid rationales for the occurrence of unemployment. The models include competitive model of unemployment, search-matching model (Stigler, 1962; Phelps, 1970; McCall, 1970), efficiency wage theory (Yellen, 1984), workers' motivation and bargaining among others.

\subsubsection{Theories and Theoretical Models of Trade and Unemployment}

The prediction of classical theory of trade leads to many outcomes. ${ }^{3}$ One of these outcomes of classical theory of trade is that trade has capability to generate employment. However, most of the models that are based on the classical theory of trade produce ambiguous findings. According to Dutt et al. (2009), trade based on the Ricardo's comparative advantage affects unemployment through differences in technologies among the countries in the world. The transmission mechanism through which trade influences unemployment is that trade increases the marginal productivity of workers in the exporting sector owing to an increase in the domestic relative prices of the goods and services produced in the sector. Since it is assumed that trade would lead to specialization, the marginal productivity of workers in the import-competing sector of the economy will fall due to trade liberalization. Aggregately, the marginal productivity of all the workers in the economy will rise owing to increase in efficiency which leads to increase in investment, resulting in more job creation, thereby reduces unemployment.

3 Classical theories of Trade include Adam Smith's Absolute Advantage, Ricardo's Comparative Advantage, Hecksher-Ohlin model to mention but a few. 
In the case where comparative advantage is based on $\mathrm{H}-\mathrm{O}$ model, unemployment is affected through international differences in relative factor endowments. This makes the outcomes controversial because it depends on the factors of production a country is blessed with. In the labor abundant economy, comparative advantage based on $\mathrm{H}-\mathrm{O}$ model will reduce unemployment but unemployment may rise in capital-abundant economy. Using these two classical trade theories to build the model of trade liberalization and unemployment, Dutt, et al., (2009) found a robust empirical support for the Ricardian theory of trade prediction and no support for H-O model prediction. Before Dutt et al., (2009), Davidson et al., (1999) and Moore and Ranjan (2005) had developed models linking trade with unemployment. While in Davidson et al's model, comparative advantage arises as a result of difference in search technologies and/or job breakup rates to explain the impact of trade on unemployment and the welfare of the unemployed, Moore and Rajan (2005) based their comparative advantage on difference in skilled-based technology to bring about implication for unemployment and wage inequality. In recent time, other researchers have sought to theoretically explain the rationales for trade and unemployment nexus (see Helpman and Itskhoki, 2010, Mitra and Ranjan 2010, Felbermayr et al. 2010, Hassan et al. 2011). Their conclusions however differ. In Felbrermayr et al. (2010) model, trade liberalization-unemployment reducing nexus is driven by productivity. Accordingly, an increase in overall productivity caused by trade liberalization occurs through the forcing out of the least productive firms and the reallocation of labor into more productive firms in the model of heterogeneous firm productivity. Helpman and Itskjoki (2010), however, reported opposite results where two forms of sector modelled yielded the same results. Apart from a differentiated products, heterogeneous productive sector with labor market frictions where trade results in higher aggregate productivity in the differentiated products sector with cumulative expansionary spill-over effect on the size of the sector and the other sector. This leads to fall in unemployment.

\subsection{Empirical Literature Review}

Taking clue from theories, several attempts have been made to empirical examine the determinants of unemployment in different countries around the world. It has been argued that several factors tend to determine unemployment. These factors may be internal or external and they vary from one country to the others based some socioeconomic and political fundamentals such as institutions, legal frameworks and market settings that are peculiar to a specific country.

To begin with, Magbool et al., (2013) comprehensively examined the effect of some macroeconomic variables on unemployment rate in Pakistan over a period of 1976-2013. Using autoregressive distribution lag model, they found that macroeconomic variables such as GDP, population, inflation, FDI were crucial determinants 
of unemployment in Pakistan both in the short-run and long-run. In specific terms, their study showed that all the aforementioned variables were correctly signed in the sense that they had negative effects on unemployment. Akin to their findings, Oniore et al., (2015) concluded that GDP growth rate, inflation rate, degree of openness and private domestic investment exhibited short-run and long-run relationship with unemployment in Nigeria. However, while it was shown that GDP growth rate and inflation had reducing effects on unemployment, degree of openness, and domestic private investment worsened unemployment in Nigeria. Contrary to Oniore et al. (2015), O'Nwachukwu (2017) noted that real GDP did not have any significant effect on unemployment rate in Nigeria but only government expenditure, inflation rate and population had significant effects on unemployment rate. In Ghana, BaahBoateng, (2013), who considered both demand factors and supply factors as determinants of unemployment, discovered that high growth generates weak employment. Also, he found that, in some instance, education and gender played significant roles in determining unemployment rate. A priori, reservation wages was found to worsen unemployment. On the determinant of youth unemployment in Romania, Condratov, (2014) carried out a survey of literature and found that demographic structure, economic environment, regulations of labor and education system were the key determinants of youth unemployment in Romania. In Limpopo province in South Africa, Kyei and Gyekye examined the factors that determine unemployment in the province. Through their study, they showed that GDP, male, matriculation, and youth had no important bearing on unemployment but females, postgraduate studies, middle aged, primary, incomplete secondary schooling and race were important determinants of unemployment in the province in South Africa. Folawewo and Adeboje (2017), instead of focusing on country-specific study, considered the macroeconomic determinants of unemployment in the region of West Africa. Their findings depicted that though GDP had a reducing effect on unemployment, the effect was however insignificant. Also, inflation, labor productivity and population were found to have an increasing effect on unemployment. They equally documented that FDI and external debt had weak effects on unemployment.

Due to some recent occurrences in international arena, economists have begun to examine other factors that serve as determinants of unemployment. Issues such as immigration and trade, in recent time, have become hot debate as citizens from one country to other worry about the implications of immigration and trade for their employability. On how immigration can affect unemployment, Latif, (2015) who used the provincial level panel data from Canada and employed the series of econometric techniques such as FMOLS, DOLS and VECM, found that immigration aggravated unemployment in the short run but reduced it in the long run. He also showed that there was unidirectional Granger-causality between immigrant and unemployment with causality running from immigration to unemployment. In France, Fromentin, (2017) examined the relationship between immigration and unemployment and 
found that in the long-run there is no observable increase in aggregate unemployment due to immigration. When VECM estimation method was employed, immigration had a negative effect on unemployment. In the case of OECD countries, Jean and Miguel, (2011) studied the effect of immigration on unemployment over the period of 1984,-2003. Their results showed that immigration had a temporary impact on natives' unemployment.

On the impact of international trade on unemployment rate, studies are inexhaustible but characterized with mixed findings. While some studies such as Felbrermayr et al (2009); Dutt, Mitra and Ranjan, (2009), Kim (2011), Loganathan et al., (2011), Hassan, et al. (2012) as well as Anyanwu, (2014) agreed that trade openness and unemployment were inversely related, that is, trade openness reduced unemployment, there were ample of other studies such as Davis (1998), Egger and Kreickemeier (2009), Helpman and Itskhoki (2010) and Nwaka, et al. (2015) suggested that trade openness worsened unemployment. Deviation from the two contracting sides above are the studies such as Sener (2001) and Moore and Ranjan (2005) who concluded that trade openness had no direct effect on unemployment. Even in the case where reducing effect exists between trade openness and unemployment rate, Kim (2011) noted that such effect was hampered by labor market rigidity and regulations.

Despite the huge literatures on the effects trade openness on unemployment, little attention has been paid to the possibility of effect of current account balance on unemployment rate. However, there are scanty literatures that have tried to look at this issue. Theoretical relationship between current account and unemployment is provided by the studies of Mayer (2010) and Eaton, Kortum and Neiman, (2013). Besides the aforementioned theoretical studies, there are two empirical studies that specifically focus on the nexus between current account and unemployment (Hojjat, 2014 and Ozer and Yeldan, 2016). While Hojjat, (2014) examined the relationship between current account balance and unemployment in the United States, Ozer and Yeldan, (2016) looked at the relationship between current account deficits and unemployment in Turkey. Using both descriptive analysis and Ordinary Least Squares estimation approach, Hojjat, (2014) reported that there was a significant correlation between current account balance and unemployment and that improvement in current account balance brought about decline in unemployment rate in the United States. In a similar way, though employed different methodological approach, Ozer and Yeldan, (2016) used Vector Error Correction Model (VECM) in conjunction with Impulse Response and Variance Decomposition approaches and documented that there was existence of a unidirectional causality between current account deficits and unemployment that the causality ran from current account deficits to unemployment. 


\section{METHOD AND MATERIALS}

\subsection{Method: Autoregressive Distribution Lag (ARDL)}

This study is specifically designed to examine trade openness and current account balance as determinants of unemployment in Nigeria. In order to do this, $\mathrm{Au}$ toregressive Distribution Lag (ARDL) estimation technique developed by Pesaran, Shin and Smith (2001) was employed. We employed this method for two reasons. First, ARDL technique is useful for time series analysis irrespective of order of integration of the variables, either order 1 or o. In other words, one can conveniently use ARDL estimation technique for level stationary or fist difference stationary variables. Second, ARDL technique combines the estimation of both short and long runs together, a major important advantage over estimation techniques that deal with the short-run and the long-run issues such as Engle and Granger as well as Johansen estimation tests. Thus, following Pasaran, Shin and Smith (2001) framework, we specify the model as follows:

$$
\begin{aligned}
& \text { unemp }_{t}=\alpha_{0}+\lambda_{1} \text { unemp }_{t-1}+\lambda_{2} c a b_{t-1}+\lambda_{3} c p i_{t-1}+\lambda_{4} r G D P_{t-1}+\lambda_{5} \text { open }_{t-1}+\lambda_{6} \text { exrate }_{t-1}+\lambda_{7} f d i_{t-1} \\
& +\lambda_{8} r G G C E_{t-1}+\lambda_{9} \text { wag }_{t-1}+\sum_{i=1}^{n} \beta_{i} \Delta \text { unemp }_{t-1}+\sum_{i=0}^{m 1} \delta_{i} \Delta \text { cuact }_{t-1}+\sum_{i=0}^{m 2} \phi_{i} \Delta c p i_{t-1}+\sum_{i=0}^{m 3} \varphi_{i} \Delta r G D P_{t-1}+ \\
& \sum_{i=0}^{m 4} \gamma_{i} \Delta \text { open }_{t-1}+\sum_{i=0}^{m 5} \mu_{i} \Delta \text { exrate }_{t-1}+\sum_{i=0}^{m 6} \pi_{i} \Delta f d i_{t-1}+\sum_{i=0}^{m 7} \vartheta_{i} \Delta r G G C E_{t-1}+\sum_{i=0}^{m 8} \theta_{i} \Delta w a g_{t-1}+\varepsilon_{t}
\end{aligned}
$$

Where signifies the first difference operator, $\alpha_{0}$ denotes drift component, $\varepsilon_{\mathrm{t}}$ is the white noise or error term, $\lambda_{1}$ to $\lambda_{9}$ are the long-run multiplier of each of the variable or the long run relationship between the variables, $\beta i, \delta_{t}, \phi_{i}, \varphi_{i}, \gamma_{i}, \pi_{i}, \mu_{i} \vartheta$ and $\theta_{i}$ with signs summation are the short-run dynamic variables, the variables unemp, cab, cpi, rGDP, open, exrate, fdi, rGGCE and wag are unemployment rate, curent account balance, consumer price index (inflation), real gross domestic product, trade openness, exchange rate, foreign direct investment, government consumption expenditure and compensation of employee (wage) respectively. All variables are logged except current account balance for it has been expressed as a percentage of GDP. Equation 1 comprises of two parts. The first part of the equation captures the long-run equation while the second equation with lags captures dynamic short-run equation.

The null hypothesis governing the use of ARDL cointegration test is that there is no long-run relationship between our variables of interest. This is depicted as:

Long run Null Hypothesis (Ho)

$$
\lambda_{1}=\lambda_{2}=\lambda_{3}=\lambda_{4}=\lambda_{5}=\lambda_{6}=\lambda_{7}=\lambda_{8}=\lambda_{9}=0
$$


Long-run Alternative Hypothesis $\left(\mathrm{H}_{\mathrm{l}}\right)$

$$
\lambda_{1} \neq \lambda_{2} \neq \lambda_{3} \neq \lambda_{4} \neq \lambda_{5} \neq \lambda_{6} \neq \lambda_{7} \neq \lambda_{8} \neq \lambda_{9} \neq 0
$$

Previously, particularly in the early day of application of ARDL in empirical studies, the calculated F-test value obtained from the estimation of the above equation would be compared with the lower and upper critical values given in the Pesaran et al., (2001) table. If the F-test value obtained is greater than the Pesaran et al's upper critical value, then it means there is cointegration, that is, there is long-run relationship and the null hypothesis of no cointegration is not accepted. However, if the F-test value is less than the lower critical value, then there is no long-run relationship. The decision is inconclusive, if the F-test value lies in-between the upper and the lower critical values.

Building on the proof of existence of cointegration among the variables, the study would proceed to the estimation of the error correction model (ECM). The ECM shows the speed of adjustment to the long-rum equilibrium after initial shortrun disequilibrium in the economy. The ECM model is specified as follows:

$$
\begin{aligned}
& \Delta \text { unemp }_{i}=\alpha_{0}+\sum_{i=1}^{n} \beta_{i} \Delta \text { unemp }_{t-1}+\sum_{i=0}^{m 1} \delta_{i} \Delta \text { cuact }_{t-1}+\sum_{i=0}^{m 2} \phi_{i} \Delta c p i_{t-1}+\sum_{i=0}^{m 3} \varphi_{i} \Delta r G D P_{t-1}+\sum_{i=0}^{m 4} \gamma_{i} \Delta \text { open }_{t-1}+\sum_{i=0}^{m 5} \mu_{i} \Delta \text { exrate }_{t-1}+ \\
& \sum_{i=0}^{m 6} \pi_{i} \Delta f d i_{t-1}+\sum_{i=0}^{m 7} \gamma_{i} \Delta r G G C E_{t-1}+\sum_{i=0}^{m 8} \theta_{i} \Delta \text { wag }_{t-1}+\varpi E C M_{t-1}+\varepsilon_{t}
\end{aligned}
$$

Where: $E C M$ = error correction model term and othervariables remain as defined in equation 1

In recent time, however, EVIEWS Software computes Bound testing approach to cointegration as well as both short-run dynamic and long-run estimation automatically and generate both F-test value and Pesaran et al., (2001)'s critical table for decision making about whether the variables of interest are cointegrated or not

\subsection{Material: Data Sources and Descriptive Statistics}

The study examines the link between trade openness, current account balance and unemployment rate in Nigeria employing the annual data that span from 1981 to 2014. The data were sourced from the World Development indicators (2016) version, the Nigerian Bureau of Statistics and Central Bank of Nigeria Statistical Bulletin. Unemployment rate, obtained from National Bureau of Statistical, is the percentage of people who are willing to work at prevailing wage rate but unable to find job. Current account balance and compensation of employees are obtained from the Central Bank of Nigeria Statistical Bulleting. While current account balance provides a revelation about the trading position of Nigeria with the rest of the world (whether Nigeria is a creditor or debtor to the rest of the world), compensation of employee is the aggre- 
gate amount of wages accrued to workers annually. Consumer price index (a measure of price level in the economy), real gross domestic product which captures economic performance measured in local currency unit, trade openness expressed as the summation of exports and imports divided by GDP and multiplied by 100 stands for how the country is opened to the rest of the world in terms of its trading activities, exchange rate measures the domestic currency in terms of foreign currency, foreign direct investment captures foreigners' investment in Nigeria (inflow FDI) and government consumption expenditure stands for the amount of money the government spent on the provision of public goods- are all extracted from World Development Indicators. The descriptive results of the variables are presented in the Table 1 . From the table, it can be shown that most of the variables recorded moderate variability and are normally distributed as shows by standard deviation and Jaque-Bera normality test.

Table 1.: Descriptive Statistics of the Variables

\begin{tabular}{|l|r|r|r|r|r|r|r|r|r|}
\hline Variable & LUNEMP & CAB & LCPI & LRGDP & LOPEN & LOEXRAT & LVFDI & LRGGCE & LWAG \\
\hline Mean & 2.024 & 10.369 & 2.525 & 30.931 & 3.897 & 3.165 & 21.143 & 27.133 & 10.495 \\
Median & 1.909 & 12.145 & 3.218 & 30.725 & 3.997 & 3.092 & 21.087 & 26.383 & 10.468 \\
Maximum & 3.311 & 29.830 & 4.982 & 31.850 & 4.404 & 5.066 & 22.903 & 29.258 & 12.379 \\
Minimum & 0.588 & -12.240 & -0.706 & 30.355 & 3.162 & -0.482 & 19.058 & 26.100 & 8.860 \\
Std. Dev. & 0.799 & 10.595 & 1.927 & 0.472 & 0.350 & 1.937 & 1.108 & 1.265 & 1.029 \\
Skewness & 0.006 & -0.277 & -0.405 & 0.715 & -0.739 & -0.682 & 0.008 & 0.856 & 0.352 \\
Kurtosis & 1.776 & 2.395 & 1.656 & 1.976 & 2.492 & 2.105 & 2.057 & 1.876 & 1.946 \\
Jarque-Bera & 2.122 & 0.953 & 3.488 & 4.380 & 3.459 & 3.769 & 1.261 & 5.939 & 2.276 \\
Probability & 0.346 & 0.621 & 0.175 & 0.112 & 0.177 & 0.152 & 0.532 & 0.051 & 0.320 \\
Observations & 34 & 34 & 34 & 34 & 34 & 34 & 34 & 34 & 34. \\
\hline
\end{tabular}

Source: Author's computation using EVIEWS 9 software

Note: All the variables except current account scaled by GDP are in logged forms. LUNEMP $=\log$ of unemployment rate, $\mathrm{CAB}$ = current account balance scaled by GDP, LCPI = log of consumer price index proxied for inflation, LRGDP = log of real GDP, LOPEN = log of trade of openness, LOEXRAT = log of nominal exchange rate, LVFDI = log of value of foreign domestic investment, LRGGCE = log of real government consumption expenditure, $\mathrm{LWAG}=\log$ of compensation of employee proxied for wage

\section{EMPIRICAL RESULTS AND DISCUSSION}

\subsection{Correlation Matrix Results}

Table 2. presents the results of correlation matrix analysis of the variables. The correlation matrix analysis is done for two major reasons. First is to determine the degree of association between two or more variables. Second is to detect the degree of multicollinearity among the explanatory variables. From the table, it can be shown that most of the independent variables are positively and significantly correlated with unemployment 
rate except current account balance which is only positively but insignificantly associated with unemployment rate. In specific terms, inflation rate, real GDP, exchange rate, foreign direct invest, government consumption expenditure and wages have correlation coefficients of $0.655,0.828,0628,0.646,0.773$ and 0.612 respectively. Conversely, trade openness exhibits negative insignificant relationship with unemployment rate with correlation coefficient of -0.011. Among the explanatory variables, more moderate correlations can also be observed except on some occasions when independent variables are occasionally highly correlated among themselves. However, this does not pose a threat to our model and empirical findings because the Variance Inflating Factor (VIF) that shows the degree of interconnection among the variables which results in the inflation of variance and covariance of estimated parameters of model as $R_{X Y}^{2}$ increases does not exceed the tolerable level. According to Asteriou and Hall, (2007, pp. 90) states that VIF that is not exceed $10 \%$ does not pose multicollinearity threat to econometric model. VIF exceeds 10\% when $R_{X Y}^{2}>0.9$. For instance, foreign direct investment and government consumption expenditure are highly correlated with real GDP with correlation coefficient (r) equals $0.77^{3}$ which when squared; it yields $R_{X Y}^{2}$ of 0.598 which is less than to 0.9 benchmark criterion. Even where it appears that $R_{X Y}^{2}>0.9$ as in the case of association between real exchange rate and consumer price index and that of government consumption expenditure and economic growth, the post estimation technique, particularly Breusch-Godfrey Serial Correlation LM Test with probability value of 0.4449 shows that there is no problem of multicollinearity in our model.

Table 2.: Correlation Matrix of the Variables

\begin{tabular}{|c|c|c|c|c|c|c|c|c|c|}
\hline \multicolumn{10}{|c|}{ CORRELATION ESTIMATION RESULTS } \\
\hline Variable & LUNEMP & CAP & LCPI & LRGDP & LOPEN & LOEXRAT & LVFDI & LRGGCE & LWAG \\
\hline LUNEMP & 1.000 & & & & & & & & \\
\hline $\mathrm{CAB}$ & 0.017 & 1.000 & & & & & & & \\
\hline LCPI & $0.655^{* * * *}$ & $-0.383^{* *}$ & 1.000 & & & & & & \\
\hline LRGDP & $0.828^{* * * *}$ & -0.161 & $0.850^{* * * *}$ & 1.000 & & & & & \\
\hline LOPEN & -0.011 & -0.093 & $0.449^{* * * *}$ & 0.088 & 1.000 & & & & \\
\hline LOEXRAT & $0.628^{* * * *}$ & $-0.315^{*}$ & $0.966^{* * * *}$ & $0.772^{* * *}$ & $0.539^{* * * *}$ & 1.000 & & & \\
\hline LVFDI & $0.646^{* * *}$ & -0.183 & $0.885^{* * * * *}$ & $0.887^{* * * *}$ & $0.404^{* *}$ & $0.849^{* * * *}$ & 1.000 & & \\
\hline LRGGCE & $0.77^{3 * * *}$ & -0.055 & $0.755^{* * * *}$ & $0.966^{* * * *}$ & -0.003 & $0.677^{* * * *}$ & $0.85^{8 * * *}$ & 1.000 & \\
\hline LWAG & $0.612^{* * * *}$ & 0.131 & 0.278 & $0.715^{* * *}$ & $-0.437^{* * * *}$ & 0.159 & $0.47^{8^{* * * *}}$ & $0.817^{* * * *}$ & 1.000 \\
\hline
\end{tabular}

Source: Author's computation using EVIEWS 9 software

Note: ${ }^{* * *},{ }^{* *}$ and $*$ represent $1 \%, 5 \%$ and $10 \%$ levels of significance respectively Probability values are in parenthesis

\subsection{Time Series Unit Root Test Results}

We employed two time series unit root tests-augmented Dickey-Fuller and Philip-Perron unit root tests. The unit root test is carried out with the objective of determining the stationarity properties of our variables of interest so as to avoid any 
form of spurious regression. Thus, Table 3. presents the results of unit root test based on the Augmented Dickey-Fuller and Philip-Perron unit root tests. The results show that all the variables are integrated of order 1 . In other words, all the variables contain unit root at level, that is, they are trending with time or not stationary at level but only made stationary after they are first differenced.

Table 3.: Unit Root Test Results

\begin{tabular}{|c|c|c|c|c|c|}
\hline \multirow[b]{2}{*}{ Variable } & \multicolumn{2}{|c|}{$\begin{array}{l}\text { AUGMENTED DICKEY-FULLER } \\
\text { (CONSTANT) }\end{array}$} & \multicolumn{2}{|c|}{ PHILLIP-PERRON (CONSTANT) } & \multirow[b]{2}{*}{$\begin{array}{l}\text { Order of } \\
\text { Integration }\end{array}$} \\
\hline & Level & First Difference & Level & First Difference & \\
\hline LUNEMP & $-0.4750(0.8836)$ & $-5.0856 *(0.0002)$ & $-0.5^{8} 79(0.8601)$ & $-5.0769^{*}(0.0002)$ & $\mathrm{I}(1$ \\
\hline $\mathrm{CAB}$ & $-2.6722(0.0896)$ & $-5.7213^{*}(0.0000)$ & $-2.7075(0.0835)$ & $-6.84 .64^{*}(0.0000)$ & $\mathrm{I}(1$ \\
\hline LCPI & $-1.4671\left(0.5^{366}\right)$ & $-3.2893^{* * *}(0.0241)$ & $-1.4419(0.5499)$ & $-2.9029^{* * * *}(0.0561)$ & $\mathrm{I}(1$ \\
\hline LRGDP & $1.7605^{2}(0.9995)$ & $-4.247^{8 *}(0.0022)$ & $1.7605(0.9995)$ & $-4.2329 *(0.0023)$ & $\mathrm{I}(1$ \\
\hline TOPEN & $-1.8845(0.3352)$ & $-7.4070^{*}(0.0000)$ & $-1.9018(0.327 .5)$ & $-7.4 .070^{*}(0.0000)$ & $\mathrm{I}(1$ \\
\hline LOEXRAT & $-2.0103(0.2812)$ & $-4.8471^{*}(0.0004)$ & $-2.1413(0.2307)$ & $-4.8471^{*}(0.0004)$ & $\mathrm{I}(1$ \\
\hline LVFDI & $-0.7890(0.8087)$ & $-10.9284^{*}(0.0000)$ & $-1.2592(0.6365)$ & $-10.7823^{*}(0.0000)$ & $\mathrm{I}(1$ \\
\hline LRGGCE & $-0.0430(0.9476)$ & $-6.0694^{*}(0.0000)$ & $-0.0115(0.9508)$ & $-6.0544^{*}(0.0000)$ & $\mathrm{I}(1$ \\
\hline LWAG & $-0.7219(0.8274)$ & $-6.4108 *(0.0000)$ & $-0.6598(0.8432)$ & $-6.3976^{*}(0.0000)$ & $\mathrm{I}(1$ \\
\hline
\end{tabular}

Source: Author's computation using EVIEWS 9 software

Note: ${ }^{*},{ }^{* *}$ and ${ }^{* * *}$ represent $1 \%, 5 \%$ and $10 \%$ levels of significance respectively

Probability values are in parenthesis

\subsection{Cointegration Test Results}

Having determined the order of integration of our variables, we proceeded to determine whether these variables are cointegrated, that is, whether they possess a long-run relationship. In order to achieve this and for consistency, two sets of cointegration tests were carried out-Johansen cointegration test and Peseran Bound testing cointegration method. Cointegration test, particularly Johansen cointegration test, is sensitive to choice of lag length. Thus, one lag length was selected for Johansen cointegration test to avoid the problem singular matrix. Table 4. and 5. present the results of both Johansen and Pesaran cointegration tests respectively. The results from the tables show that our variables of interest are cointegrated, that is, the null hypothesis of no cointegration among the variables is not accepted. In other words, our variables of interest possess a long run relationship. In specific terms, results from Johansen cointegration test show that for trace test, there are 5 cointerating equations while for maximum eigenvalues test there are 3 cointegrating equations. On bound testing cointegration method; the F-test statistical value of 5.067 is greater than the upper bound critical value of 3.06 at 1 per cent level of significance, thereby showing that there is a long-run relationship among the variables, that is, our model is cointegrated. 
Table 4.: Johansen Cointegration Test Results

\begin{tabular}{|c|c|c|c|c|c|c|c|}
\hline \multicolumn{4}{|c|}{ TRACE TEST $\mathrm{K}=1$} & \multicolumn{4}{|c|}{ MAXIMUM EIGENVALUES TEST K = } \\
\hline Ho & $\mathbf{H}_{\mathrm{A}}$ & $(\lambda$ trace $)$ & $\begin{array}{c}\text { Critical } \\
\text { values } \\
(5 \%)\end{array}$ & Но & $\mathbf{H}_{\mathrm{A}}$ & $(\lambda$ Max $)$ & $\begin{array}{c}\text { Critical } \\
\text { values } \\
(5 \%)\end{array}$ \\
\hline$r \leq 0$ & $\mathrm{r}>0$ & $412.219(0.0000)$ & 197.371 & $\mathrm{r} \leq 0$ & $\mathrm{r}>0$ & $171.331(0.0000)$ & $5^{8.4} \cdot 34$ \\
\hline$r \leq 1$ & $\mathrm{r}>1$ & $240.888(0.0000)$ & $159 \cdot 5^{30}$ & $r \leq 1$ & $\mathrm{r}>1$ & $83.230(0.0000)$ & 52.363 \\
\hline$r \leq 2$ & $r>2$ & $157.65^{8}(0.0001)$ & 125.615 & $r \leq 2$ & $\mathrm{r}>2$ & $48.935(0.0251)$ & 46.231 \\
\hline$r \leq 3$ & $\mathrm{r}>3$ & $108.724(0.0047)$ & $95 \cdot 754$ & $\mathrm{r} \leq 3$ & $\mathrm{r}>3$ & $37.968(0.084 .8)$ & $40.07^{8}$ \\
\hline$r \leq 4$ & $r>4$ & $70.756(0.0420)$ & 69.819 & $r \leq 4$ & $r>4$ & $32.197(0.0782)$ & 33.877 \\
\hline $\mathrm{r} \leq 5$ & $\mathrm{r}>5$ & $38.559(0.2782)$ & 47.856 & $\mathrm{r} \leq 5$ & $r>5$ & $20.916(0.2814)$ & $27.5^{84}$ \\
\hline$r \leq 6$ & $r>6$ & $17.64 .3(0.5925)$ & $29 \cdot 797$ & $r \leq 6$ & $r>6$ & $10.75^{3(0.6719)}$ & 21.132 \\
\hline $\mathrm{r} \leq 7$ & $\mathrm{r}>7$ & $6.890(0.5905)$ & 15.495 & $\mathrm{r} \leq 7$ & $\mathrm{r}>7$ & 5.457 (0.6834) & 14.265 \\
\hline $\mathrm{r} \leq 8$ & $\mathrm{r}>8$ & $1.433(0.2313)$ & 3.841 & $\mathrm{r} \leq 8$ & $\mathrm{r}>8$ & $1.433(0.2313)$ & 3.841 \\
\hline
\end{tabular}

Source: Author's computation using EVIEWS 9 software

Note: Probability values that signify the level of significance are put in parenthesis. Also, $r$ represents number of cointegrating vectors and $\mathrm{k}$ represents the number of lags in the unrestricted VAR model.

Table 5.: Pesaran, Shin and Smith Bounds Testing Cointegrating Results

\begin{tabular}{|c|c|c|}
\hline $\begin{array}{l}\text { Test Statistic } \\
\text { F-Statistic }\end{array}$ & $\begin{array}{l}\text { Value } \\
5.067\end{array}$ & $\begin{array}{l}K \\
8 \\
\end{array}$ \\
\hline \multicolumn{3}{|c|}{ Critical Value Bounds } \\
\hline Significance & I(o) Bound & I(1) Bound \\
\hline $10 \%$ & 1.95 & 3.06 \\
\hline $5 \%$ & 2.22 & 3.39 \\
\hline $2.5 \%$ & 2.48 & 3.7 \\
\hline $1 \%$ & 2.79 & 4.1 \\
\hline
\end{tabular}

Source: Author's computation using EVIEWS 9 software

\subsection{Short-run and Long-run ARDL Model Results}

Sequel to cointegration tests, we estimated the short-run dynamic and long-run effects of trade openness and current account balance on unemployment rate using ARDL method. The results of this experiment are presented in Table 6. Beginning from error correction term in the short run model, the unrestricted ECM follows a priori expectation in that it is statistically significant at -0.246 . This implies that when an economy is in disequilibrium position such as unemployment crisis, it adjusts by one-fourth within first year of disequilibrium. In other words, it will take about four years for economy to converge towards long run equilibrium. This implies 
that any policy by authority to bring economy to equilibrium (in this case to address unemployment) will take about 4 years to have a full effect. This connotes a moderate convergence of the Nigerian economic model.

Making reference to Table 6. again, our results show that current account balance in the short run worsens unemployment rate for it is positively and significantly related to unemployment rate. Specifically, we found that an increase in current account balance by one per cent results in an increase in unemployment rate by 0.008 per cent in the short run. This can be explained that in the short run Nigeria probably experiences current account surplus that contributes to soaring unemployment rate. This, however, runs contrary to a priori expectation. Theoretically, it is expected that when a country experiences current account surplus, unemployment rate is supposed to decline drastically due to its improvement in the export segment of its international transactions. However, in the literature of international trade, a country may record current account surplus which shows that the country has great export competitiveness but such country may have deficit in its capital account. Capital account deficit may connote capital outflow or flight from the economy which may be an offshoot of lack of confidence in the domestic economy by the foreign investors due to macroeconomic crisis or during major significant economic recession. Whether current account surplus will lead to more employment therefore depends on whether export competitiveness outweighs capital flight. In the long run, we found that current account balance has a negative and significant effect on unemployment rate. This implies that current account lowers unemployment rate in the long run. More specifically, one per cent improvement in current account lowers unemployment rate by 0.10 per cent. This finding is akin to finding of Hojjat, (2014) who discovered in the United States when there is improvement in the current account balance, unemployment rate falls. Our finding can be explained in this sense, in the long run, Nigerian economy probably records current account deficit which help in lowering her unemployment crisis. Current account deficit may be considered to be harmful to the economy in the sense that it shows that imports are greater than the exports. However, current account deficit may mean there is a surplus in the financial aspect of current account. In other words, current account deficit could be inflow of capital which could be used for investment in the domestic economy and thereby generate more employment and reduce unemployment rate.

As touching the effect of trade openness on the unemployment rate, our results show that trade openness worsens unemployment rate in Nigeria both in the short run and in the long run, albeit with different magnitudes. In more specific terms, a one per cent increase in trade openness would lead to increase in unemployment rate by 0.700 and 4.321 per cents both in the short-run and the long-run respectively. The results suggest that trade openness has been continuously led to high unemployment rate in Nigeria. Since in most trade literature, trade openness is often used to proxy the trade liberalization, it therefore implies that policy of trade liberalization 
is not favorable to Nigerian economy. This result may be attributed to the labor institutional market condition in the country because it has been argued that where there is pronounced restrictive labor market regulation and more prevalent of informal labor market, trade openness may worsen unemployment rate (Menezes-Filho and Muendler, 2011). Our results are also akin to the finding of Nwaka et al., (2015) who found that trade liberalization proxied by trade openness worsens unemployment in Nigeria.

Apart from the effects of current account and trade openness on the unemployment rate in Nigeria, we also considered other factors that could have greater influence on unemployment rate. These variables include consumer price index (inflation), real GDP, exchange rate, foreign direct investment, government consumption expenditure as well as the compensation of employee (wages). The results of this experiment are also presented in table 6 . From the table inflation rate is negatively and significantly related to unemployment rate both in the short-run and in the longrun. This suggests that an increase in inflation rate would bring about a decline in unemployment rate in Nigeria. To be more specific, a one per cent increase in inflation rate will bring about 0.788 and 0.736 per cent decline in unemployment rate in the short-run and in the long-run respectively. This finding is consistent with the a priori expectation that posits that when inflation is rising, unemployment should be declining-Philips curve prediction pointed out by Philips, (1958). Working on the trade-off between inflation and unemployment rate, Mankiw (2001) noted that there is only short run trade-off between inflation and unemployment rate due to monetary policy shock by the monetary authority. Our finding also supports the one obtained by Furuoka and Munir (2014) who found a negative long run relation between inflation and unemployment rate for Malaysia. Thus, inflation rate reduces unemployment rate in both short run and long run. On the other hand, real GDP seems to worsen unemployment problem though its effect is statistically insignificant in Nigeria both in the short run and the long run. For instance, we discovered that an increase in real GDP by one lead to 0.7759 and 3.084 per cent increase in unemployment rate in the short and the long run respectively. Our findings suggest that growth in Nigeria is not pro-employment generation which is contrary to the theoretical prediction (Okun's Law).

In addition, we observed that exchange rate and foreign direct investment are germane to reduction of unemployment rate in Nigeria for both variables have negative and significant effect on unemployment rate in Nigeria both in the short-run and the long run. For instance, when exchange rate and foreign direct investment improve by one per cent, unemployment rate will decline by 0.018 and 0.4 .87 per cent in the short run and 0.074 and -3.771 per cent in the long run respectively. These findings suggest that improvement in exchange rate (domestic currency visà-vis of foreign currency) is one of the solutions to unemployment problem in Nigeria. The result is plausible one because theoretically improvement in a country's 
exchange rate (improvement home currency in terms of other trading countries' currencies) stimulates the country's exports which would lead to increase in the ability of firms, particularly the export oriented firms to employ more workforces. This finding is akin to the one obtained by Bakhshi and Ebrahimi (2016) who discovered that there is a negative relationship between exchange rate and unemployment for Iranian economy. In terms of the effect of foreign direct investment on unemployment rate, this study shows that FDI is indispensable to Nigerian economy as shown above, particularly real FDI (establishment of new factories by foreign investors in the domestic economy) often leads to employment of more labor force or workers and thus leads to reduction in employment rate. Our result could find allies in many empirical findings in the literature on FDI-unemployment rate nexus (Craigwell, 2006; Zeb et al., 2014; Shaari et al., 2012, Karlsson, et al., 2009 and Habib and Sarwar, 2013). Concerning the effect of government consumption expenditure on unemployment rate; our results show that government expenditure worsens unemployment rate both in the short-run and the long run. For example the results from table 6 show that if government increase its consumption expenditure by one per cent, unemployment rate rises by 0.658 and 4.368 per cent in the short-run and the long-run respectively. The results are however run contrary to a priori expectation and this may not be unconnected with some augments in public sector economics that government sometimes does engage in unproductive investment or spending. On the final note, our results show that wage rate reduces unemployment rate in $\mathrm{Ni}$ geria both in the short-run and the long-run; however, only short-run coefficient is statistically significant $5 \%$ level. While the classical school of thought favors reduction in wages to stimulate employment so as to reduce unemployment, Keynesian favors increase in wages will stimulate employment and thus reducing unemployment, provided there is an increase in price level which makes real wages to remain unchanged. This connotes that our finding corroborates Keynesian Theory of wages and unemployment.

In order to prove the reliability of our results, we carried out diagnostic tests which include normality, serial correlation, and heteroscedasticity as well linearity or functional form tests. The results of these various diagnostic tests are presented in Table 6. The overall results show that all the models pass all the tests conducted. Thus, the models are reliable and can be used for economic policy, forecasting and prediction. 
Table 6.: Short-run and Long-run Autoregressive Distribution Lag Results

\begin{tabular}{|c|c|}
\hline \multicolumn{2}{|c|}{ ARDL Short-run Cointegration Form } \\
\hline Variable & Coefficient \\
\hline $\mathrm{CAB}$ & $\begin{array}{l}0.008 * \\
(2.074)\end{array}$ \\
\hline LCPI & $\begin{array}{l}-0.788^{* *} \\
(-2.3 \circ 8)\end{array}$ \\
\hline LEGDP & $\begin{array}{l}0.759 \\
(1.352)\end{array}$ \\
\hline LOPEN & $\begin{array}{l}0.700^{* *} \\
(2.823)\end{array}$ \\
\hline LOEXRAT & $\begin{array}{l}-0.018 \\
(-0.214)\end{array}$ \\
\hline LVFDI & $\begin{array}{l}-0.487^{* * *} \\
(-4.222)\end{array}$ \\
\hline LRGGCE & $\begin{array}{l}0.65^{8 * *} \\
\left(2.5^{18}\right)\end{array}$ \\
\hline LWAG & $\begin{array}{l}-0.432^{* *} \\
(-2.285)\end{array}$ \\
\hline $\operatorname{CointEq}(-1)$ & $\begin{array}{l}-0.246^{* *} \\
(-2.799)\end{array}$ \\
\hline
\end{tabular}




\begin{tabular}{|c|c|}
\hline \multicolumn{2}{|c|}{ ARDL Long-run Coefficients } \\
\hline Constant & $\begin{array}{l}-126.702^{*} \\
(-2.054)\end{array}$ \\
\hline $\mathrm{CAB}$ & $\begin{array}{l}-0.100^{*} \\
(-2.017)\end{array}$ \\
\hline LCPI & $\begin{array}{l}-0.7^{3} 4 \\
(-1.396)\end{array}$ \\
\hline LEGDP & $\begin{array}{l}3.084 \\
\left(1.5^{6} 5\right)\end{array}$ \\
\hline LOPEN & $\begin{array}{l}4.321^{*} \\
(2.048)\end{array}$ \\
\hline LOEXRAT & $\begin{array}{l}-0.074 \\
(-0.207)\end{array}$ \\
\hline LVFDI & $\begin{array}{l}-3.77^{* *} \\
\left(-2.5^{11}\right)\end{array}$ \\
\hline LRGGGE & $\begin{array}{l}4.364^{*} \\
(2.098)\end{array}$ \\
\hline LWAG & $\begin{array}{c}-1.755 \\
(-1.728)\end{array}$ \\
\hline $\mathrm{R}^{2}$ & $0.9809(98.09 \%)$ \\
\hline Adjusted $\mathrm{R}^{2}$ & $0.9661(96.61 \%)$ \\
\hline F-statistic (prob) & $66.056(0.0000)$ \\
\hline Durbin-Watson Stat & 2.2810 \\
\hline
\end{tabular}




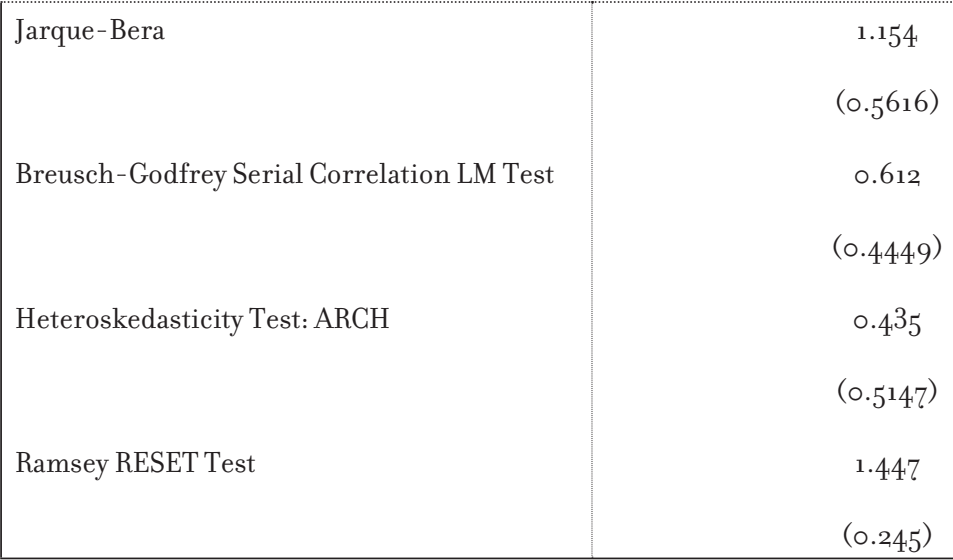

Source: Author's computation using EVIEW 9 software

Note: Number of models evaluated: 256

Selected Model: ARDL (1, 1, 1, ०, 1, ०, 1, 1, ०)

Model selection method: Alkaike Info Criterion (AIC)

No. of lag selected: 1 lag period

*** and ${ }^{* * *}$ represent $1 \%, 5 \%$ and $10 \%$ levels of significance respectively

\section{CONCLUSION AND POLICY RECOMMENDATIONS}

This study is designed specifically to empirically examine how trade openness and current account balance have affected the unemployment rate in Nigeria. To achieve this objective, the study employed the novel time series econometric technique developed by Pesaran et al., (2001)-ARDL Bound Test to Cointegration. Applying this novel estimation technique, the results are much more revealing. First, on the effect of current account balance on the unemployment rate in Nigeria, our study show that there is no clear cut effect because current account balance could worsen or improve the unemployment situation depending on the time dimension under consideration and the state of the economy. However, what is apparent from this study is that in the short run, current account balance seemed to worsen the unemployment situation while in the long run it seemed to improve it. It is therefore become imperative that the authority in charge of trade and investment to be cognisance of the movement of events in the international transactions in terms of volume and nature of transactions in real and portfolio trade. Second, it is unarguable that trade openness does not favor the developing countries, particularly Nigeria. Several studies, not this alone, have shown empirically that trade openness worsens unemployment situation in Nigeria. This may be attributed to a considerable number of factors which may include the state of our economy, the status and the competiveness of our firms or industries, the nature of goods and services put forward for transaction and the nature of some of our institutions put in place to oversee the international transactions. Thus government, therefore, needs to be more proactive in terms of put- 
ting policies in place and provide infrastructure facilities required to encourage the domestic firms to be more productive and competitive in the international market. Also there is need to strengthen the weakened institutions. In specific terms, while trade restriction policies are no more encouraged in the international arena, a more reasonable ways of protecting the growing domestic firms or industries must be put in place. Besides, since financial backing is indispensable for the survival of firms, it is imperative for government to reduce the cost of borrowing and even gives financial consideration to some specific firms in the sectors where the majority of citizens are seeking employment. We also discovered in the course of this study that despite the fact that the country has recorded some remarkable growth (not until recently) particularly in this democratic dispensation, the growth has not been pro-poor or pro-employment. As economy is growing, unemployment rate is also increased astronomically. Many factors may be responsible for this phenomenon. However, the salient questions in this case include: which sector is driving the growth? Can the sector employment more people? Do people or citizens possess the technical knowhow required by the sector? Answers to these questions will guide the policymakers on how to design policies that would make growth pro-employment. If the sector that is driving growth cannot employ more people or people do not have required technical know-how by the sector, then government should focus more on other sectors where the skills of the citizens can be mostly employed and educate them along that sector so that they can be more employable and be productive. The policy implications of other factors that affect unemployment rate considered in this study are that government should pursue sound macroeconomic policies in more aggressive and holistic ways that will be favorable to both domestic and foreign firms so that they can serve as hubs of employment generation and thereby contribute to reduction in unemployment rate in Nigeria as it is apparent that government alone may not be able to provide employment to all the citizens.

\section{ACKNOWLEDGEMENT}

The Author will like to thank the two anonymous referees and the excellent assistance provided by Mr. Oludele Folarin. Any other observed mistakes are the responsibility of author. 


\section{REFERENCES}

Anyanwu, John C. "Does Intra African Trade Reduce Youth Unemployment in Africa?" African Development Review 26, no. 2 (2014): 286-309

Asteriou, D., and S. G. Hall. "Applied econometrics: A modern approach using eviews and microfit revised edition: Palgrave Macmillan." (2007)

Baah-Boateng, W., "Determinants of unemployment in Ghana", African Development Review, Vol. 25, No. 4, (2013): $385^{-399}$

BakhshiZ and Ebrahimi M., "The effect of real exchange rate on unemployment", Marketing and Branding. Research, 2, (2015): 4,-13

Blanchard, Olivier. "Monetary policy and unemployment." In Remarks at the Conference" Monetary Policy and the Labour Market: A Conference in Honor of James Tobin", New School University. 2003.

Brecher, R., "Minimum wage rates and the pure theory of international trade", Quarterly Journal of Economics 88(4), (1974): 98-116

CBN, 2013, "Annual Statistical Bulletin", Central Bank of Nigeria, Various Issues

CBN, 2014, "Annual Statistical Bulletin", Central Bank of Nigeria, Various Issues

Choudhry, M. T., Marelli, E. and Signorelli, M. 2012, "Youth unemployment rate and impact of financial crises", International Journal of Manpower, Vol. 33, No.1, (2012): 76-95

Ciżkowicz, Piotr, Michał Kowalczuk, and Andrzej Rzońca. "Heterogeneous determinants of local unemployment in Poland." Post-Communist Economies 28, no. 4 (2016): 487-519

Condratov, I. 2014, "Determinants of youth unemployment: a survey of literature", ECOFORUM, Vol. 3, Issue 2(5).

Craigwell, Roland. "Foreign direct investment and employment in the English and Dutch-speaking Caribbean." Project prepared for ILO, Trinidad and Tobago (2006)

Davidson, Carl, and Steven Joseph Matusz. International trade and labor markets: Theory, evidence, and policy implications. WE Upjohn Institute, 2004.

Davidson, Carl, Lawrence Martin, and Steven Matusz. "Trade and search generated unemployment." Journal of International Economics 48, no. 2 (1999): 271-299

Davis, D. R., "Does European unemployment prop up American wages? National labour markets and global trade", American Economic Review, 88, (1998): 478-494

Dutt, P. Mitra, D. and. Ranja, P., "International trade and unemployment: theory and cross-national evidence", Journal of International Economies, 78(1), (2009): 32-44

Eaton, Jonathan, Samuel Kortum, and Brent Neiman. "On Deficits and Unemployment." Revue économique 64, no. 3 (2013): 4.05-420

Egger, H., and U. Kreickemeier. 2009, "Firm heterogeneity and the labor market effects of trade liberalization" International Economic Review 50 (1), (2009): 187-216

Essien, Sunday N., Garba A. Manya, Mary OAArigo, Kufre J. Bassey, Suleiman F. Ogunyinka, Deborah G. Ojegwo, and Francisca Ogbuehi. "Monetary Policy and Unemployment in Nigeria: Is there a Dynamic Relationship?." Cbn Journal Of Applied Statistics 7 (2016)

Eze, O. R. and Uwambeke, G. C., "Effect of deficit financing on unemployment rate in Nigeria: An error 
correction model", International Journal of Small Business and Entrepreneurship Research, Vol. 3, No. 7 , (2015): $28-46$

Fajana, S. "Functioning of the Nigerian Labour Market, Labonfin and Company, Lagos." Provide page $(2000)$

Felbermayr, Gabriel, Julien Prat, and Hans-Jörg Schmerer. "Globalization and labor market outcomes: Wage bargaining, search frictions, and firm heterogeneity." Journal of Economic theory 146, no. 1 (2011): $39^{-} 7^{3}$

Felbermayr, Gabriel, Julien Prat, and Hans-Jörg Schmerer. "Trade and unemployment: What do the data say?." European Economic Review 55, no. 6 (2011): $741^{-}-75^{8}$

Folawewo, Abiodun O., and Oluwafemi M. Adeboje. "Macroeconomic Determinants of Unemployment: Empirical Evidence from Economic Community of West African States." African Development Review 29, no. $2(2017): 197^{-210}$

Fromentin, Vincent. "The relationship between immigration and unemployment: The case of France." Economic Analysis and Policy 43, no. 1 (2013): 51-66

Furuoka, Fumitaka, and Qaiser Munir. "Unemployment and Inflation in Malaysia: Evidence from Error Correction Model." Malaysian Journal of Business and Economics (MJBE) 1 , no. 1 (2014)

Habib, Malik Danish, and Saima Sarwar. "Impact of foreign direct investment on employment level in Pakistan: A Time Series Analysis." JL Pol'y \& Globalization 10 (2013): 46

Hasan, Rana, Devashish Mitra, Priya Ranjan, and Reshad N. Ahsan. "Trade liberalization and unemployment: Theory and evidence from India." Journal of Development Economics 97, no. 2 (2012): 269-280

Helpman, Elhanan, and Oleg Itskhoki. "Labour market rigidities, trade and unemployment." The Review of Economic Studies 77, no. 3 (2010): 1100-1137

Hojjat, Mehdi. "Will the Unemployment Rate Fall with a Robust Forecast for the US Current Account Balance?." Journal of Economic \& Financial Studies 2, no. ०4 (2014): 28-33

IMF, 2010, "IMF survey: sharp rise in unemployment from global recession. IMF survey online" http://www. imf.org/external/pubs/ft/survey/so/2010/NEWogo210A.htm

Jean, Sebastien, and Miguel Jiménez. "The unemployment impact of immigration in OECD countries." European Journal of Political Economy 27, no. 2 (2011): 241-256

Karlsson, Sune, Nannan Lundin, Fredrik Sjöholm, and Ping He. "Foreign firms and Chinese employment." The World Economy 32, no. 1 (2009): 178-201

Keynes, J., "The general theory of employment, interest and money", London: Harcourt, (1936)

Kim, J., 2011, "The effect of trade on unemployment: Evidence from 20 OECD countries" Department Economies, Stockholm University, Sweden.

Kyei, Kwabena A., and Kwame B. Gyekye. "Determinants of unemployment in Limpopo province in South Africa: exploratory studies." Journal of Emerging Trends in Economics and Management Sciences 2, no. 1 (2011): 54-61

Latif, Ehsan. "The relationship between immigration and unemployment: Panel data evidence from Canada." Economic Modelling 50 (2015): 162-167

Loganathan, Nanthakumar, Muhammad Najit Sukemi, and Mori Kogid. "Dynamic causal relationship between trade balance and unemployment scenario in Malaysia: granger non-causality analysis."

Economics and Finance Review 1, no. 3 (2011): 13-20 
Mankiw, N. Gregory. "The inexorable and mysterious tradeoff between inflation and unemployment." The Economic Journal 111, no. 471 (2001): 45-61

Maqbool, Muhammad Shahid, Tahir Mahmood, Abdul Sattar, and M. N. Bhalli. "Determinants of unemployment: Empirical evidences from Pakistan." Pakistan Economic and Social Review (2013): 191-208

Mayer, J., 2010, "Global rebalancing: Effects on trade flow and employment", UNCTAD Discussion Paper, No.200.

McCall, John Joseph. "Economics of information and job search." The Quarterly Journal of Economics (1970): 113-126

McDonald, Ian M., and Robert M. Solow. "Wage bargaining and employment." The American Economic Review 71, no. 5 (1981): 896-908

Menezes-Filho N. A. and Muendler M. A., 2011, "Labour reallocation in response to trade reform", NBER Working paper 17372. Cambridge, MA: National Bureau of Economic Research Inc

Mitra, Devashish, and Priya Ranjan. "Offshoring and unemployment: The role of search frictions labor mobility." Journal of International Economics 81, no. 2 (2010): 219-229

Moore, Mark P., and Priya Ranjan. "Globalisation vs Skill Biased Technological Change: Implications for Unemployment and Wage Inequality." The Economic Journal 115, no. 503 (2005): 391-422

Mouhammed A. H., "Important theories of unemployment and public policies" Journal of Applied Business and Economies, Vol. 12(5), (2011): 100-110

NBS, 2014, "The review of definition and methodology for computing unemployment statistics in Nigeria" Report of National Stakeholders' Workshop held at Ayalla Hotel, Garki, Abuja, 8-10, September, 2014.

Nwaka, Ikechukwu D., Kalu E. Uma, and Gulcay Tuna. "Trade openness and unemployment: Empirical evidence for Nigeria." The Economic and Labour Relations Review 26, no. 1 (2015): 117-136

Nwankwo, Cosmas Anayochukwu, and Adaobi Patrictia Ifejiofor. "Impact of unemployment on Nigerian economic development: a study of selected local government area in Anambra State, Nigeria." European Journal of Business and Management 6, no. 35 (2014): 103-112

Okun, A. M., "Potential GNP: Its measurement and significance", Proceeding of the Business \& Economic Statistics Section of the American Statistical Association, (1962): 98-104

O'Nwachukwu C. I., "Determinants of the rate of unemployment in Nigeria" Information Journal of Information Research and Review, Vol. ०4, Issue o1, (2017): 3593-3595

Oniore J. O. Bernard A. O. and Gyang E. J., "Macroeconomic determinants of unemployment in Nigeria" International Journal of Economics, Commerce and Management, Vol. III, Issue 10, (2015): 215-230

Ozer, Mustafa, and A. ErinçYeldan. "The Relationship between Current Account Deficits and Unemployment in Turkey." In Handbook of Research on Comparative Economic Development Perspectives on Europe and the MENA Region, pp. 492-510. IGI Global, 2016.

Pesaran, M. Hashem, Yongcheol Shin, and Richard J. Smith. "Bounds testing approaches to the analysis of level relationships." Journal of applied econometrics 16, no. 3 (2001): 289-326

Phelps, Edmund S. "Microeconomic foundations of employment and inflation theory." (1970)

Phillips, A.W., "The relationship between unemployment and the rate of change of money wage rates in the United Kingdom 1861-1957", Economica, 25 (100), (1958): 283 - 299 
Pigou, A. C., "The theory of unemployment", London: Macmillan, (1933)

Rad, Sahar Taghdisi. "Jordan's paradox of growth without employment." Development Viewpoint 65 (2011)

Rogerson, Richard, Robert Shimer, and Randall Wright. "Search-theoretic models of the labor market: $A$ survey." Journal of economic literature 43, no. 4. (2005): 959-988

Schmillen, Achim, and Joachim Möller. "Distribution and determinants of lifetime unemployment."

Labour Economics 19, no. 1 (2012): 33-47

Schumpeter, J., "Theory of economic development", Cambridge, MA.: Harvard University Press, 1934.

Şener, Fuat. «Schumpeterian unemployment, trade and wages.Č Journal of International Economics 54 , no. 1 (2001): $119^{-14}, 8$

Shaari, M. S., Hussain, N. E and Halim, M. S. B. A., "The impact of foreign direct investment on the unemployment rate and economic growth in Malaysia", Journal of Applied Sciences Research, 8(9) (2012): 4900-4.906

Shapiro, Carl, and Joseph E. Stiglitz. "Equilibrium unemployment as a worker discipline device." The American Economic Review 74, no. 3 (1984): 433-444

Stigler, George J. "Information in the labor market." Journal of political economy 70, no. 5, Part 2 (1962): 94-105

Veblen, Thorstein. The theory of business enterprise. C. Scribner's sons, 1904.

Verick S. and Islam, I., 2010, "The great recession of 2008-2009: causes, consequences and policy responses", IZA Discussion Paper NO. 4934.

WDI, 2015, "World development indicators", World Bank

Yellen J. L., "Efficiency Wage Models of Unemployment" The American Economic Review, Vol. 74, No. 2 Papers and Proceedings of the Nineth-Sixth Annual Meeting of the American Economic Association, (1984): 200-205

Zeb N., Qiang, F. and Sharif, M. S., "Foreign direct investment and unemployment reduction in Pakistan", International Journal of Economic Resource. Vol. 5, Issue 2, (2014): 10-17 